\title{
Elementary School Teachers' Understanding of Nature of Science: a Study on Rural, Bordered, Coastal, and Urban Areas of North Kalimantan
}

\author{
Muhsinah Annisa \\ Department of Elementary School Teacher Education \\ Faculty of Teacher Training and Education \\ Borneo University Tarakan \\ Tarakan, Indonesia
}

\author{
Listiani \\ Department of Biological Education \\ Faculty of Teacher Training and Education \\ Borneo University Tarakan \\ Tarakan, Indonesia \\ listiani.asrin84@gmail.com
}

\begin{abstract}
It cannot be denied that people face various issues and they have to make decisions for those issues. People should have appropriate knowledge to make decision. Mostly, the most important knowledge that people have to know is science, especially to know that science is a process. In order to know science as process, people should have understanding in nature of science. The best way to introduce the nature of science is teaching in basic level of formal education, which is elementary school. Therefore, elementary school teachers have to understand the nature of science concept so they can integrate it during teaching and learning process. Because of the importance of understanding the nature of science, having information on elementary school teachers' understanding on nature of science is crucial. One of instruments that can be used to assess this knowledge is View of Nature of Science (VNOS) form B. This instrument was given to thirty-six elementary school teachers from four different areas in North Kalimantan. The result shows that there are $72 \%$ respondents who have no understanding in nature of science, $23 \%$ respondents are having little understanding in nature of science, and the rest understand nature of science. It can be concluded that most of elementary school teachers in North Kalimantan do not understand the nature of science concepts.
\end{abstract}

Keywords-Nature of Science; Elementary School Teachers; Science Education

\section{INTRODUCTION}

Recently, the educational system has been focused on achieving scientifically literate society and emphasizing on nature of science understanding. The understanding of nature of science will lead the community to be smarter and more selective in using scientific information. By understanding the nature of science, we are expecting to have effective societies locally and globally [1]. The nature of science understanding is related to the ability of the society in knowing science thoroughly and implementing what they have in their community. The societies who are understanding the nature of science are expected to think scientifically and wisely in facing each science and social problem.
Undoubtedly, the development of science and technology requires people to be wiser and more careful in using information and technology. On the other hand, people have to be more open minded and high curiosity so they can follow the development of science. In order to prepare future generation who are ready in facing challenge in the future, they have to be provided with science starting from elementary school since elementary school is the basic education that is important for the next level of education. Therefore, elementary school as one of a formal education should have teachers with good qualification because they are responsible for preparing student for facing their future. Indeed, they have to have knowledge in nature of science so they can teach their students how to understand the nature of science. It is impossible to integrate the nature of science in teaching if the teachers do not understand what the nature of science is.

Unfortunately, research in nature of science either focusing on teachers' understanding, preservice teachers' understanding, and students' understanding is limited. Indeed, there are no research researches on nature of science conducted in Tarakan. Tarakan is a small city located in bordered are of Indonesia that is typically experience problem in education. Because of its location, Tarakan needs attention from government and others, especially in education, either in facilitation or in human resources. This is important because Indonesia have to prepare the society to compete nationally and even internationally. In addition, people have to be able to make decision for many issues, especially in science.

One of international issues in education that we have to pay attention is scientific literacy. In formal education, scientific literacy can be taught starting from introducing the nature of science. Because of its important, teaching and integrating nature of science in science teaching especially in elementary education in crucial. In order to provide students with nature of science knowledge, the teachers have to have this knowledge first. Therefore, research in analyzing elementary school teachers' understanding of nature of science in Tarakan is important. There are several instruments that can be used to measure the nature of science. This research is using VNOS 
(View of Nature of Science) form B developed by Abd-ElKhalick [2] that has been translated and adapted culturally into Bahasa Indonesia. The VNOS form B is an instrument with open-ended questions. The result of this questionnaire then will be analyzed descriptively to determine the understanding of the nature of science. The result then can be used as information about teachers' nature of science understanding. Furthermore, the information can be used for consideration whether the elementary school teachers need to have training in nature of science and its implementation in teaching or not.

\section{METHOD}

This is a qualitative research. The data that has been collected then being analyzed descriptively to describe elementary school teachers' understanding of nature of science. Sample of this research was selected from four different areas in North Kalimantan which are consisted of rural area (Long Peso), bordered area (Sebatik), Urban area (Tarakan), and coastal area (Derawan).There are five selected schools as the sample of this research. The sample was selected based on purposive sampling method, which considers on the accreditation of those schools. There are three science schools, who are selected as samples for each school. Those teachers then were given NOS instrument questionnaire. The instrument that is used for this research is VNOS form B. Translating and adapting process of this instrument has been done based on Montoya et al. [3].Montoya says that there are two steps on transadaptation process which consist of translating process and validation process (Figure 1).In translating and adapting the instrument, the researchers should consider the suitability of the content with Indonesian culture and language [4].

The first step of transadaptation is translating process. In this step, the original instrument that is presented in English then being translated into Bahasa Indonesia. After that, the researcher asked for a person who is expert in English to translate back the Indonesian version of the instrument into English. When the first step is completed then continue into the second step, which is validation. The validation step consists of 3 kinds of test. The first test is comparison which is comparing both languages (English and Bahasa Indonesia) in term of similarity of words, phrases, and sentences. The next test is similarity and interpretability which refers to the degree to which the two versions engender the same response even if the wording is not the same. The last test is Degree of understandability, which refers to the degree of comprehension of the two versions even if the wording is different. The second phase can be repeated as required until the valid data has been obtained. Once the instrument is valid, it can be implemented in the research. In this research, the valid transadapted instrument was given to respondents who were elementary school teachers.
Phase I - Translation
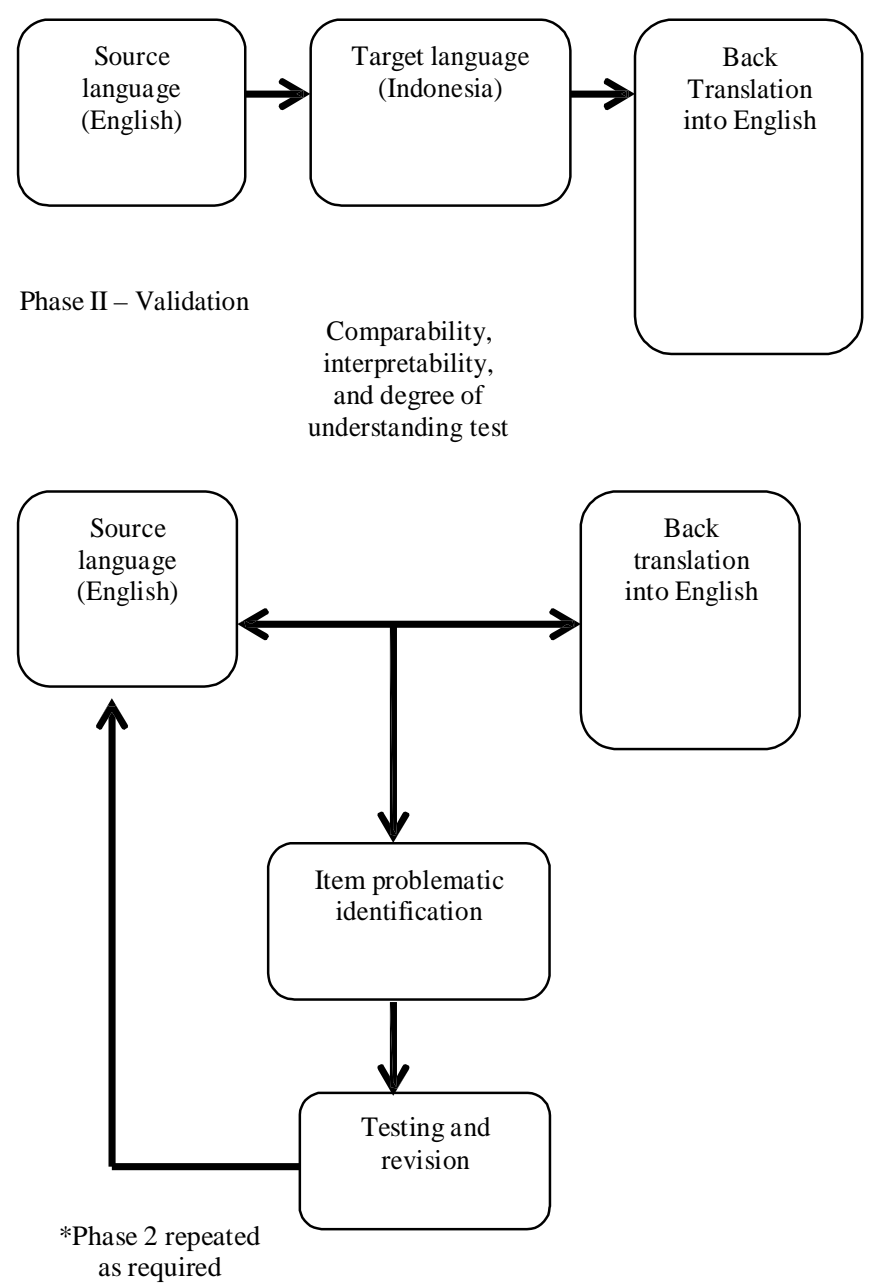

Fig 1.The diagram of translating and adapting of VNOS form B into Bahasa Indonesia

After the instrument has been translated and adapted into Bahasa Indonesia, they are distributed to the respondents. The responses from respondents are then being analyzed and described. The analysis has been done by comparing the description of NOS instrument from Lederman [5] and therespondent responses. The respondent responses then can be categorized into three categories: Do not understand the NOS aspects, having little understanding on the NOS aspects, and understand the NOS aspects. At the end of analyzing process, the percentage of each category can be compared and described.

\section{RESULT AND DISCUSSION}

\section{A. The View of Nature of Science}

Research on view of nature of science has been done in 4P areas. The areas consist of rural, bordered, coastal, and urban areas in north Kalimantan. Elementary school teachers in Long 
Peso is the representation respondents from rural area, elementary school in Sebatik is the representation of respondents from bordered area, elementary school in Derawan is the representation of coastal area, and elementary school teachers in Tarakan is the representation of urban area. Each respondent was given a questionnaire that has been transadapted from VNOS form B. Those respondents were required to answer the questionnaire that will represent their understanding on nature of science.

It is important to know the view of nature of science because nature of science understanding is related to the understanding of basic science concepts. The result shows that most of elementary school teachers in $4 \mathrm{P}$ areas do not understand the basic concept and aspects on nature of science (Figure 2). It is clear that there are more than $70 \%$ of respondents have no understanding on the nature of science and only $5 \%$ of respondents have the view of nature of science. While the other which is the $20 \%$ of respondents have little understanding on the aspects of nature of science. Interestingly, most of respondents who do not have the view of nature of science clearly stated that they do not know the answer of the question. On the other hand, respondents who have little understanding and understand on nature of science have shown that they know the view of nature of science.

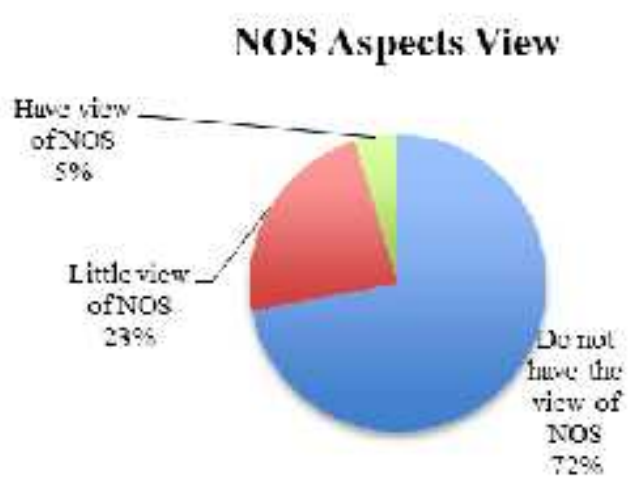

Fig 2. General view of elementary school teachers Nature of Science aspects in $4 \mathrm{P}$ areas

\section{B. The Importance of Studying Elementary School Teachers View of Nature of Science}

Recently, research on education has been intensively focused on many aspects. One of the prominent research is research on science education. This situation has been triggered by various aspect, one of the aspects is the survey result conducted by PISA [6] that study the level of students ability in reading, science, and mathematics. Surprisingly, the result shows that Indonesia is in the rank of 63 from 72 participated countries. This shows that students in Indonesia are left far behind other world countries, especially in science. Moreover, Indonesia is not better than Thailand. Therefore, it is important to reformate education in Indonesia, especially in science education.

Related to this issue, one of ways that can be implemented to make better science education in Indonesia is by preparing the teachers and the preservice teachers, especially science teachers from elementary school to secondary school so that they are qualified, understand science and are able to teach science appropriately to students. Therefore, assessment on teachers' knowledge is absolutely important. Teachers are the facilitator on learning process. It is important for teachers to understand the concepts that they are going to teach. The understanding on science concepts can be related to the understanding on nature of science. In order to study the understanding of nature of science, Lederman [2] explains that teachers who do not have the view of nature of science are potentially experience misconception. If the teachers are still struggling with misconception, they will lead their students to have misconception too. Moreover if the misconception is happening during basic level of education and without being identified and solved, it will be brought into higher level of education that will result in severe misunderstanding.

Studying the view of nature of science of elementary school teachers is important because those this is related to their understanding on basic science concepts [2]. VNOS form B is the instrument that can be used to measure teachers' view of nature of science consists of science concepts and science aspects showing the understanding on science concepts. When respondents are able to answer each question in the questionnaire appropriately, the respondents probably understand concepts in science. Therefore, elementary school teachers who can answer the questionnaire, they can be categorized as informed respondents and having good basic understanding in science.

Furthermore, the view of nature of science is also closely related to understand science as scientific product that consists of facts, concepts, theories, principles, and models. On the other hand, as a process, science is set of hands-on activities, experiments, and projects that are aimed to investigate phenomena on our surroundings. This skill consists of the ability on observing, data collecting, data processing, data interpretation, concluding, and communicating the result [7].

Moreover, science as attitude is related to activities that can be seen from thinking process of each person who are working on their expertise. Thinking process cannot be observed directly because it is related to human mind and cognitive. However, this process can be reflected on people attitude and activities. Since science is a process, therefore it is expected that during learning science and scientific process, people will understand what the scientific products are and they will be more open-minded. On the other hand, people are also expected to be more objective, have specific orientation, responsible, hard worker, polite, there will be results such as scientific products, open minded thinking, objective, orientation, thorough thinking, and others [7].

Because science is important for daily life, Indonesian government responses this by revising Indonesian curriculum. It is expected that the new curriculum will give better education for Indonesian education. This new curriculum called as curriculum 2013. In this curriculum, teachers are required to implement scientific approach. This scientific approach will guide students to understand and implement scientific principles that consist of observing, questioning, 
collecting data, associating data, communicating, and creating. Therefore, the aim of implementing curriculum 2013 is for facilitating students to balance their knowledge, skill, and obtain important values.

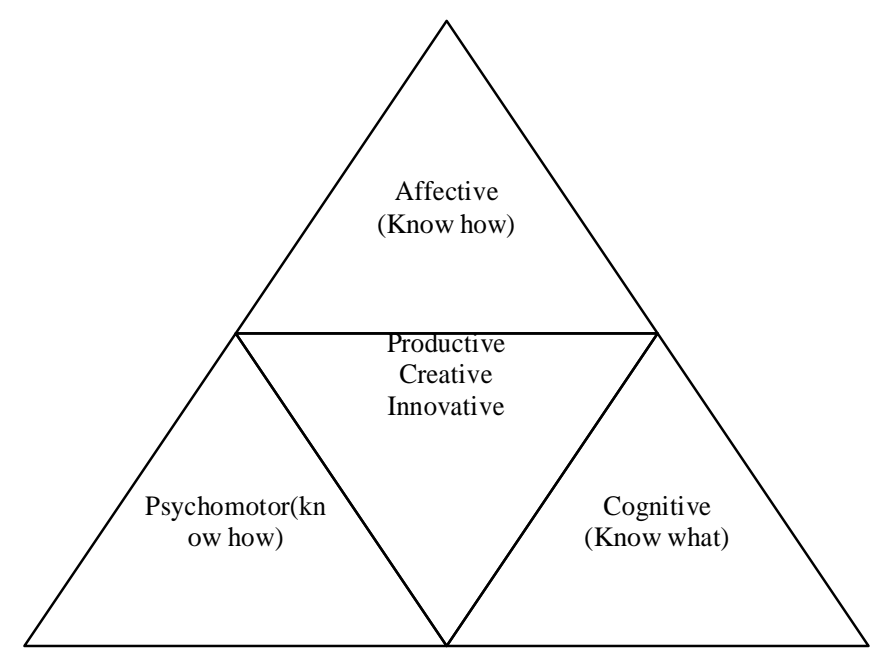

Fig 3. The components of knowledge that students should have

Because of the important of the view of nature of science, therefore teachers, especially elementary school teachers should have this understanding in order to realize the government program in implementing scienti.fic approach in teaching and learning. As a result, teachers should have the view of nature of science and know the importance of learning science

\section{Elementary School Teachers View of Nature of Science in 4P Areas (Rural, Bordered, Coastal, and Urban)}

Research on studying the view of nature of science in $4 \mathrm{P}$ areas shows that there are more than $70 \%$ of respondents who do not understand the nature of science. Respondents are categorized as novice in nature of science if they cannot answer the questions at all or they have tried to answer the questions but the answer do not relate to the question. On the other hand, there are $23 \%$ respondents who are categorized as having little understanding on nature of science. Having little understanding on nature of science category is based on respondent responses on the questionnaire. Those respondents elicit nature of science aspects on their responses. Lastly, there are only $5 \%$ of respondents that can be categorized as informed respondents who have view on nature of science. These respondents understand aspects on nature of science. According to the result, it can inform that education, especially science education in Indonesia is in vulnerable situation. This is because of teachers do not have adequate basic knowledge to teach. This situation will affect on students knowledge as well because teachers knowledge will be reflected on students knowledge [2].

Moreover, basic education is one of important educations so that students have to have correct understanding on basic knowledge, especially science knowledge. One of basic knowledge that should be introduced early to students is the nature of science [8]. Akerson has studied on students' view of nature of science from kindergarten to secondary school and the result showed that students in elementary schools do not have adequate view of nature of science. This shows that teachers have crucial role in introducing the nature of science. In the lower level class of elementary school, students may experience difficulties in understanding and applying the concept of nature of science, but by the time they will have many experiences and improve their knowledge so they can apply nature of science in their daily life.

Furthermore, there are several aspect in nature of science. At least, there are six aspect of nature of science that can be studied from elementary school teachers by using VNOS form B. those aspects are important in science teaching. For example, tentativeness aspect is the NOS aspect that relates to the absoluteness of science. From the research can be seen that not many respondents know that science is tentative or interchangeable through the time [5]. This phenomenon also can be found in other aspects. Another significant example can be seen from question on laws and theories. The result shows that elementary school teachers in $4 \mathrm{P}$ areas do not have adequate knowledge in describing and defining laws and theories. They also are not able to describe the relationship between laws and theories. All respondents cannot define theories and laws and tend to experience misconception in explaining the relationship between laws and theories.

Therefore, the result of this research shows that elementary school teachers, especially who are in $4 \mathrm{P}$ areas do not have adequate knowledge on nature of science. Because of the importance of having understanding on nature of science in science teaching so it is important to provide short training in introducing aspects on Nature of Science in order to avoid misconception, either teachers or students misconception. In other word, elementary school teachers the view of nature of science in $4 \mathrm{P}$ areas influence the implementation of curriculum 2013.This is because elementary school teachers have few understanding on nature of science that is related to science process. When students are taught science, they should also be taught how the knowledge is obtained, not only reading and remembering science concepts.

\section{CONCLUSIONS}

A research on the elementary school teachers' view of nature of science is important to discover whether elementary school teachers have had understanding on nature of science aspects correctly. In order to study the view of nature of science, an instrument called VNOS form B has been used to measure the view of nature of science. This instrument has been translated and adapted into Bahasa Indonesia and culturally appropriate to be implemented in Indonesia. Although this instrument has not been widely used, but it prospect on being implemented in Indonesia is good. The result shows that there are more than $50 \%$ of respondents do not have adequate view of nature of science. This situation is harm for the development of science education in Indonesia because if teachers do not have view of nature of science, they may do not have appropriate understanding on basic science concepts. If teachers do not have understanding on basic science concepts, 
they will experience misconception. This misconception can cause other misconceptions on students.

\section{ACKNOWLEDGMENT}

Our greatest thank for the Ministry of Research Technology and higher Education that has provided a fully funded for this research through PDP funding.

\section{REFERENCES}

[1] M.U. Smith, and L.C. Scharmann, Defining versus Describing the Nature of Science: A Pragmatic Analysis for Classroom Teachers and Science Educators. John Wiley and Sons, Inc, 1998.

[2] F. Abd-El-Khalick, R.L. Bell, \& Lederman, N.G, "The nature of science and instructional practice: Making the unnatural natural". Science Education, 82, 1998, pp 417-436

[3] A. Montoya, N. Llopis, \& I. Gilaberte, Validation of the translation of an instrument to measure reliability of written information on treatment choices: A study on attention deficit/hyperactivity disorder (ADHD). Education for Health, 24 (3). http://www.educationforhealth.net, 2011.

[4] Listiani and A.E. Kusuma, View of Nature of Science (VNOS) Form B: Sebuah Instrumen untuk Mengetahui Pemahaman Konsep Hakikat Sains Calon Guru di Universitas Borneo Tarakan. Jurnal Pendidikan Biologi Indonesia. Vol. 3. No. 1, 2017, pp $45-54$

[5] N.G Lederman, F. Abd-El-Khalick, R. L Bell, and R. Schwartz, Views Nature of Science Questionnaire: Toward Valid and Meaningful Assessment of learners' Conception of Nature of Science, 2002.

[6] OECD, Excellence and Equity in Education. PISA 2015 in Focus 2016. Retrieved from www.oecd.org, 2016

[7] V.L., Akerson, G. A. Buck, L.A. Donnelly, V. Nargund-Joshi, dan I.S. Weiland, "The Importance of Teaching and Learning Nature of Science in the Early Chilhool Years". Journal of Science Education and Technology. Vol. 20, 2011, pp 537-549.

[8] Y. Yorozu, M. Hirano, K. Oka, and Y. Tagawa, "Electron spectroscopy studies on magneto-optical media and plastic substrate interface," IEEE Transl. J. Magn. Japan, vol. 2, pp. 740-741, August 1987 [Digests 9th Annual Conf. Magnetics Japan, 1982, pp 301. 